\title{
Rearing, fattening performance and slaughter indicators of lambs after selenium, zinc and vitamin E supplementation
}

\author{
MIROSŁAW GABRYSZUK, KARINA HORBAŃCZUK and JÓZEF KLEWIEC \\ Institute of Genetics and Animal Breeding, Polish Academy of Sciences, Jastrzębiec, Poland
}

\section{Abstract}

The experiment was conducted on 80 Polish Merino ewes, their 82 lambs and 40 fattening rams. Merino ewes were divided into two groups: experimental $(E)$ and control (C), each composed of 40 animals. Four weeks before lambing, 1 day, 3 weeks and 6 weeks after lambing 40 ewes of the experimental (E) group received intramuscular injection of $5 \mathrm{ml} 0.1 \% \mathrm{Na}_{2} \mathrm{SeO}_{4}$ (selenium [Se]: $2.09 \mathrm{mg}$ ), $10 \mathrm{ml} 10 \% \mathrm{ZnSO}_{4}$ (Zinc [Zn]: 227 $\mathrm{mg}$ ) and $250 \mathrm{mg}$ vitamin $\mathrm{E}$ (a-tocopherol), and control group (C) - no received. From birth all the lambs were maintained with their dams and then weaned at the age of 8 weeks, placed in individual straw-bedded pens and fattened individually with a granulated concentrate mixture until reaching a body weight about $32 \mathrm{~kg}$. During fattening 20 lambs from experimental group (E) was given per os $1 \mathrm{ml} 0.1 \% \mathrm{Na}_{2} \mathrm{SeO}_{4}, 3 \mathrm{ml} 10 \% \mathrm{ZnSO}_{4}$ and 60 mg vitamin $E$ (a-tocopherol) daily, and control group (C) - no administered. The levels of $\mathrm{Se}, \mathrm{Zn}$ and vitamin $\mathrm{E}$ in the blood plasma of ewes and ram- lambs were within the reference values. The lambs born by the treated ewes $(E)$ experienced much lower body live weight at birth $(P \leq 0.05)$, body weight on day 28 and $56(P \leq 0.01)$, compared to lambs born from group $(C)$. Also the daily live weight gain from birth to 4 week and from birth to 8 week were significantly lower $(P \leq 0.05)$ in lambs born by the treated ewes. Se, $\mathrm{Zn}$ and vitamin $E$ treated rams contained less fat in leg $(P \leq 0.05)$, less fat thickness over ribs $(P \leq 0.01)$ and less fat thickness over loin-eye than non treated rams.

Keywords: selenium, zinc, vitamin E, sheep, fattening

\section{Zusammenfassung}

\section{Aufzuchtergebnisse, Mastleistung und Schlachtkörperqualität der Lämmern nach Selen-, Zink- und Vitamin-E-Versorgung}

Die Untersuchungen wurden an 80 Mutterschafen, ihren 82 Aufzuchlämmern und 40 Mastlämmern der Rasse Polnisches Merinoschaf durchgeführt. Die Mutterschafe wurden in zwei Gruppen aufgeteilt: Versuchsgruppe (E) und Kontrollgruppe (C) mit jeweils 40 Tieren. Vier Wochen vor der Ablammung und 1 Tag, 3 Wochen sowie 6 Wochen nach der

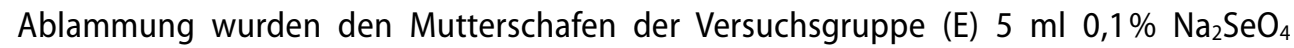

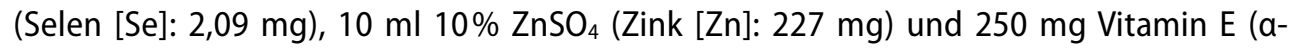
Tocopherol) intramuskulär gespritzt. Die Mutterschafe der Kontrollgruppe (C) wurden nicht behandelt. Alle Lämmer wurden bei den Müttern bis zum Alter von 8 Wochen 
aufgezogen. Anschließend wurden die männlichen Tiere zur Kraftfuttermast ad libitum in Strohstreueinzelboxen aufgestallt und bis zu einem Endgewicht von 31-32 kg gemästet. In der Mastperiode erhielten die 20 Lämmer der Versuchsgruppe (E) täglich zusätzlich per

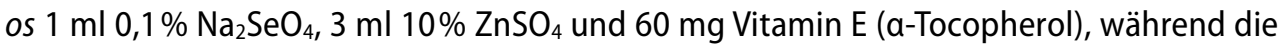
20 Lämmer der Kontrollgruppe (C) nur mit Kraftfutter gefüttert wurden. Die Blutpasmawerte von Se, Zn und Vitamin E der Mutterschafe und Mastlämmer bewegten sich innerhalb der Referenzwerte. Die von der Mutterschafgruppe E stammenden Lämmer wiesen im Vergleich mit den Lämmern der Mutterschafkontrollgruppe, signifikant geringere Lebendgewichte nach der Geburt $(P \leq 0,05)$, im Alter von 28 und 56 Tagen $(P \leq 0,01)$ auf. Auch die tägliche Zunahme des Lebendgewichts von der Geburt, bis 4 Wochen und bis 8 Wochen danach war signifikant niedriger $(P \leq 0,05)$ als bei den Lämmern der Mutterschafkontrollgruppe. Die mit Se, Zn and Vitamin E behandelten Mastlämmer wiesen einen kleineren Fettanteil in der Keule $(P \leq 0,05)$ und eine kleinere Rückenfettdicke $(P \leq 0,01)$ als die Kontrollmastlämmer auf.

Schlüsselwörter: Selen, Zink, Vitamin E, Schaf, Lämmermast

\section{Introduction}

It is widely documented that vitamins and minerals play an important role in the growth of animals and their physiological functions, as well as their reproductive performance (KOLODZIEJ and JACYNO 2005). Selenium (Se) is necessary for growth and fertility in animals and for the prevention of variety of disease conditions, which show a variable response to vitamin $E$. The metabolic function Se is closely linked to vitamin $E$ as biological antioxidant in tissue protection, but each nutrient cannot always fully compensate for a deficiency of the other (UNDERWOOD and SUTTLE 1999, KRSKA et al. 2001). The deficiency of zinc ( $\mathrm{Zn})$ was associated in all species with severe inappetence and growth depression, impaired reproductive performance and abnormalities of skin and its appendages (UNDERWOOD and SUTTLE 1999). Se, $\mathrm{Zn}$ and vitamin E are primarily active as an antioxidant protecting tissues from free-radical attack (MCDOWELL 1992). Transfer of nutrients from dam to offspring occurs via two pathways, placental transfer and colostrum/milk digestion. The amount of nutrients transferred to offspring's depends on maternal nutrient status and efficiency of transplacental and mammary transport mechanisms. Se is well transmitted through the placenta to the fetus, even in the presence of low maternal concentrations (KOLLER et al. 1984). Contrary, placental transfer of vitamin $\mathrm{E}$ is inefficient as reported by NJERU et al. (1994). By contrast CAPPER et al. (2005) reported that the vitamin E status of the neonatal and sackling lamb may be manipulated by vitamin E supplementation of the ewe during pregnancy and lactation. Se and vitamin E prepartum injections result in higher colostrum and milk concentrations of these elements (CUESTA et al. 1995). Se or Se plus vitamin E may be improved reproduction performance of ewes (SCALES 1974, GABRYSZUK 1994, ANTUNOVI et al. 2004). Survivals of lambs, live weights at birth and at weaning were increased by Se supplementation (LANGLANDS et al. 1991). Single injection of Se before lambing significantly affect lamb body weight at 28 day and daily weight gain from birth to 28 day of age (GABRYSZUK et al. 2002). Injection of Se and vitamin E together does not increased 
rearing performance in the flock considered not deficient in Se status (GABRYSZUK et al. 2002). Application of $5 \mathrm{ml} 0.1 \%$ sodium selenide before mating and lambing significantly affect Se status in blood serum and reproductive performance of ewes and body weight of lambs at 33 day of age in a Se deficient area (BALICKA-RAMISZ et al. 2006). In our earlier study on ewes the $\mathrm{Se}, \mathrm{Zn}$ and vitamin $\mathrm{E}$ intramuscular injection of ewes before and after lambing induced a decrease in cholesterol content of milk and blood, and led to increased the conjugated linoleic acid (CLA) isomers level in milk (GABRYSZUK et al. 2007b). The diet of growing ram-lambs enriched in $\mathrm{Se}, \mathrm{Zn}$ and vitamin $\mathrm{E}$ improved of lipid profile of lamb's meat (GABRYSZUK et al. 2007a).

In light of this, it is interesting whether the combined supplementation with $\mathrm{Se}, \mathrm{Zn}$ and vitamin $E$ could influence on the growing and fattening of lambs. The aim of this study was to elucidate effects of $\mathrm{Se}, \mathrm{Zn}$ and vitamin $\mathrm{E}$ supplementation of ewes and fattening ram-lambs on the rearing, fattening and slaughter performance of lambs.

\section{Material and methods}

The studies were conducted on 80 Polish Merino ewes, their 82 offspring $\left(42 q+40{ }^{\lambda}\right)$ and 40 fattening rams in the two repetitions including. In the first and second year the experiment was carried out on 80 Polish Merino ewes divided into two groups: control (C) and experimental $(\mathrm{E})$, each composed of 40 animals. Doses and the way of administration of $\mathrm{Se}, \mathrm{Zn}$ and vitamin $\mathrm{E}$ to ewes and ram-lambs from the experimental group shows Table 1.

Table 1

Doses and the way of administration of $\mathrm{Se}, \mathrm{Zn}$ and vitamin $\mathrm{E}$ to ewes and ram-lambs from the experimental group

Dosis und Art der Verabreichung von Se, Zn und Vitamin E an die Mutterschafe und Mastlämmer der Experimentalgruppe

\begin{tabular}{|c|c|c|c|c|c|}
\hline \multirow{2}{*}{ Animals } & \multirow{2}{*}{$\begin{array}{c}\text { Way of } \\
\text { administration }\end{array}$} & \multicolumn{3}{|c|}{ Doses and reagents per animal } & \multirow{2}{*}{ Time of administration } \\
\hline & & Se & $\mathrm{Zn}$ & Vitamin E & \\
\hline wes & $\begin{array}{l}\text { intramuscular } \\
\text { injection }\end{array}$ & $\begin{array}{c}5 \mathrm{ml} 1 \% \mathrm{Na}_{2} \mathrm{SeO}_{4} \\
\text { (Se: } 2.09 \mathrm{mg})\end{array}$ & $\begin{array}{c}10 \mathrm{ml} 10 \% \mathrm{ZnSO}_{4} \\
(\mathrm{Zn:} 227 \mathrm{mg})\end{array}$ & $\begin{array}{c}250 \mathrm{mg} \\
\text { a-tocopherol }\end{array}$ & $\begin{array}{c}4 \text { weeks before lambing; } \\
1 \text { day, } 3 \text { weeks and } 6 \\
\text { weeks after lambing }\end{array}$ \\
\hline Ram-lambs & orally (per os) & $\begin{array}{c}1 \mathrm{ml} 1 \% \mathrm{Na}_{2} \mathrm{SeO}_{4} \\
\text { (Se: } 0.42 \mathrm{mg})\end{array}$ & $\begin{array}{c}3 \mathrm{ml} 10 \% \mathrm{ZnSO}_{4} \\
(\mathrm{Zn}: 68 \mathrm{mg})\end{array}$ & $\begin{array}{c}60 \mathrm{mg} \\
\text { a-tocopherol }\end{array}$ & $\begin{array}{l}\text { each ram daily during } \\
\text { fattening }\end{array}$ \\
\hline
\end{tabular}

The ewes from all groups were kept in the same shed with their lambs till the age of 8 weeks. The nutrition was based on local feeds: maize silage, meadow hay, feed concentrate (oats $20 \%$, wheat bran $60 \%$, and rapeseed oilmeal $20 \%$ ) and minerals premix (about $10 \mathrm{~g}$ per ewes). The proximate analysis of feeds for ewes their nutritive value indicators, as well as $\mathrm{Zn}$ and Se content of dry matter show Table 2. In the high pregnancy period dietary intake of dry mater (DM) per ewes was $0.51 \mathrm{~kg} / \mathrm{d}$ from meadow hay, $0.67 \mathrm{~kg} / \mathrm{d}$ from maize silage and $0.86 \mathrm{~kg} / \mathrm{d}$ from concentrate. In the lactation period dietary intake of DM per ewes was $0.68 \mathrm{~kg} / \mathrm{d}$ from meadow hay, $0.67 \mathrm{~kg} / \mathrm{d}$ from maize silage and $1.04 \mathrm{~kg} / \mathrm{d}$ from concentrate. The declared content of Se, $\mathrm{Zn}$ and vitamin $\mathrm{E}$ in the mineral premix was $12 \mathrm{ppm}, 6000 \mathrm{ppm}$ and $500 \mathrm{ppm}$ respectively (Table 3). Blood samples from ewes were collected before treatment $(10 \mathrm{samples})$ and at 8 -week postpartum (10 samples from group $\mathrm{E}$ and 10 samples from group $\mathrm{C}$ ). 
Table 2

Chemical composition of feeds ( $\mathrm{g} / \mathrm{kg} \mathrm{DM}$ ) and nutritive values

Chemische Zusammensetzung des Futters ( $g / k g$ DM) und Futterwerte

\begin{tabular}{lcccc}
\hline Component & Feed concentrate $^{1}$ & Maize silage & Concentrate mixture $^{2}$ & Meadow hay \\
\hline Dry mater & 862 & 336 & 871 & 850 \\
In dry mater & & & & \\
$\quad$ Crude ash & 52 & 48 & 76 & 67 \\
Crude protein & 205 & 78 & 205 & 121 \\
Crude fibre & 101 & 211 & 76 & 315 \\
Ether extract & 39 & 34 & 52 & 18 \\
$\quad$ N-free extractives & 603 & 629 & 595 & 470 \\
Metabolizable energy MJ/kg & 12.6 & 11.8 & 12.5 & 10.2 \\
Zn mg/kg DM & 29.4 & 33.7 & 28.8 & 15.1 \\
Se mg/kg DM & 0.16 & 0.12 & 0.15 & 0.10 \\
\hline
\end{tabular}

${ }^{1}$ feed concentrate for ewes: oats $20 \%$, wheat bran $60 \%$, and rapeseed oilmeal $20 \%$, ${ }^{2}$ concentrate mixture for fattening rams: ground barley $44.1 \%$, ground oats $17 \%$, ground field bean $10 \%$, rapeseed oilmeal $25 \%$, minerals $2.9 \%$ and beet molasses $1 \%$

Table 3

Composition of mineral premix (in $1 \mathrm{~kg}$ )

Zusammensetzung des Mineralfutters (je $1 \mathrm{~kg}$ )

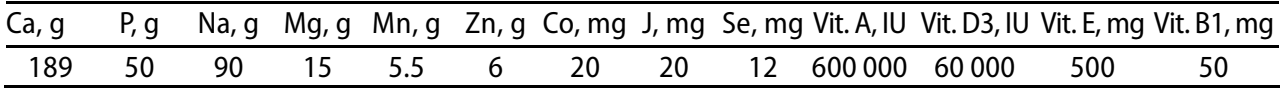

During the initial 8-week period of raising, the lambs (ewes and rams) were housed in groups with their mothers in straw lined boxes. From the second week of life all of the lambs were provided with constant access to feed concentrate and meadow hay. The amount of feed consumed during this period was not recorder. The lambs were weighed on days 1, 4 and 8 week of life.

In the age of 8 weeks 40 ram-lambs were weaned, placed in individual straw-bedded pens and fattened individually with a pelleted concentrate mixture offered ad libitum until the animals mean live weight about $32 \mathrm{~kg}$. Composition of concentrate mixture: ground barley $44.1 \%$, ground oats $17 \%$, ground field bean $10 \%$, rapeseed oilmeal $25 \%$, minerals $2.9 \%$ and beet molasses $1 \%$. Additionally, about $100 \mathrm{~g}$ hay per lamb/day was offered. The hay was not fully consumed and its intake was not recorded. During fattening period the daily amount of concentrate consumed was recorded individually. The 40 ram-lambs were divided into two groups of 20: control (C) and experimental (E). The rams in $C$ group origin from ewes of $C$ group and rams from $E$ groups origin from ewes from $\mathrm{E}$ group. During fattening, each lamb from group $\mathrm{E}$ was given daily per os $\mathrm{Se}$, $\mathrm{Zn}$ and vitamin $\mathrm{E}$ (Table 1).

Proximate analysis of feeds was performed using standard methods. The level of metabolizable energy of feed was calculated on the basis of the results of proximate analyses using the equation proposed by MAFF (1975). The proximate analysis of feeds for fattening rams, their nutritive value indicators, as well as $\mathrm{Zn}$ and Se content of dry matter shows Table 2. During fattening the animals were weighed weekly. At the end of fattening (about $32 \mathrm{~kg}$ body live weight) all lambs were slaughtered and the carcasses subjected to cutting and dissecting. At the start and at the end of fattening blood was withdrawn once from jugular vein of lambs for determination of $\mathrm{Zn}$, Se and vitamin $\mathrm{E}$. 
We collected 10 samples from group $E$ and 10 samples from group $C$ before fattening and 10 samples from group $E$ and 10 samples from group $C$ at the end of fattening. Samples of feeds and blood plasma were mineralised in a mixture of $5 \mathrm{ml} \mathrm{HNO} \mathrm{H}_{3}$ and $1 \mathrm{ml} \mathrm{H}_{2} \mathrm{O}_{2}$ in hermetic high-pressure vessels by heating in microwave oven. The $\mathrm{Zn}$ content was determined by atomic absorption spectrometry. Total Se content was estimated by flame (air-acetylene) atomic absorption spectrometry using hydrogen generation system. Se hydride was generated with $\mathrm{NaBH}_{4}$. Hallow cathode lamp $(196.0 \mathrm{~nm})$ with deuterium background correction was used. The a-tocopherol contents were determined in blood plasma by HPLC (MCMURRAY and BLANCHFLOWER 1979).

The results were subjected to multifactorial variance analysis using the least squares method (HARVEY 1990).

Assessment of the growth of all of the lambs (ewes and rams) in the rearing period was analysed using the model:

$$
Y_{i j k l}=\mu+A_{i}+B_{j}+C_{k}+D_{l}+(A B)_{i j}+e_{i j k l}
$$

Assessment of performance and slaughter value of rams was analysed using the model:

$$
Y_{i j k l}=\mu+A_{i}+B_{j}+(A B)_{i j}+e_{i j k}
$$

where $Y_{i j k(l)}$ is the analysed trait, $\mu$ the overall mean, $A_{i}$ the effect of year $(i=1,2), B_{j}$ the effect of group $(j=1,2), C_{k}$ the effect of type of birth - litter size $(k=1,2), D_{\text {l the effect of }}$ $\operatorname{sex}(I=1,2),(A B)_{i j}$ the interaction (year · group), and $e_{i j k(I)}$ the random error.

Means of Se, $\mathrm{Zn}$ and vitamin E contents in blood plasma and their standard errors were computed and differences between group means verified based on the t-test using Microsoft Excel and Statistica for Windows.

\section{Results}

Daily Se intake per ewe (groups pooled) from feeds and mineral premix in the advanced pregnancy and lactation amounted to $0.39-0.44 \mathrm{mg}$ while that of $\mathrm{Zn}$ to about $115-123 \mathrm{mg}$ (figures not tabulated). Daily Se intake per ram during fattening in C group was $0.15 \mathrm{mg}$ and $0.57 \mathrm{mg}$ in group $E$ while the respective values for $Z \mathrm{n}$ were $29.2 \mathrm{mg}$ and $97.2 \mathrm{mg}$.

$\mathrm{Se}, \mathrm{Zn}$ and vitamin $\mathrm{E}$ concentrations in the blood plasma of sheep are presented in Table 4. Comparison with references values for Se: 1.01-1.95 $\mu \mathrm{mol} / \mathrm{I}$ (HIDIROGLOU et al. 1987, JUDSON et al. 1988) for vitamin E: 2.97-13.92 $\mu \mathrm{mol} / \mathrm{I}$ (DONCON and STEEL 1988) and for Zn: 12.24-18.36 $\mu \mathrm{mol} / \mathrm{I}$ (CAॄKAŁA 1981) shows that results obtained in this experiment were within the references values. The level of $\mathrm{Se}$ in the blood plasma of experimental ewes after injection of $\mathrm{Se}, \mathrm{Zn}$ and vitamin $\mathrm{E}$ was significantly higher than control. The concentrations of $\mathrm{Se}, \mathrm{Zn}$ and vitamin $\mathrm{E}$ in the blood plasma of rams from group $\mathrm{E}$ after fattening were significantly higher than control rams. The doses of $\mathrm{Se}, \mathrm{Zn}$ and vitamin $\mathrm{E}$ applied in this experiment did not results in miscarriages, stillbirths, and the rate of twins was similar in the control and the treatment group. All lambs born were reared to 8 week in $\mathrm{E}$ and $\mathrm{C}$ group. The data presented in Table 5 show that the lambs born by the treated ewes (E) experienced much lower body live weight at birth than lambs born by control ewes. The body weight on week 4 and 8 were significantly lower $(P \leq 0.05)$ in lambs born 
from ewes which received $\mathrm{Se}, \mathrm{Zn}$ and vitamin $\mathrm{E}$ compared to control group (C). Also the daily live weight gain from birth to 4 week and from birth to 8 week were significantly lower $(P \leq 0.05)$ in lambs born by the treated ewes (Table 5$)$. In the same age at start fattening ( 55.7 and 56.4 days) rams weaned from ewes treated Se, $\mathrm{Zn}$ and vitamin E were lower body weight initial fattening $(P \leq 0.01)$ and lower $(P \leq 0.05)$ body live weight gain from birth to start fattening than rams from control group (Table 6).

Table 4

Last square mean of Se, $\mathrm{Zn}$ and vitamin E contents ( $\mu \mathrm{mol} / \mathrm{l})$ in blood plasma of sheep

Last square mean von Se, Zn und Vitamin E ( $\mu$ mol/l) im Blutplasma der Schafe

\begin{tabular}{|c|c|c|c|c|c|c|}
\hline \multirow{2}{*}{ Group } & \multicolumn{2}{|c|}{ Se } & \multicolumn{2}{|c|}{$\mathrm{Zn}$} & \multicolumn{2}{|c|}{ Vitamin E } \\
\hline & LSM & SE & LSM & SE & LSM & SE \\
\hline \multicolumn{7}{|l|}{ Ewes } \\
\hline Before injection & $1.25^{\mathrm{a}}$ & 0.11 & 14.22 & 1.67 & 3.41 & 1.16 \\
\hline \multicolumn{7}{|c|}{8 weeks after lambing } \\
\hline Group E & $1.46^{b}$ & 0.17 & 15.63 & 2.03 & 3.97 & 0.86 \\
\hline Group C & $1.12^{\mathrm{a}}$ & 0.16 & 14.03 & 1.98 & 3.12 & 0.97 \\
\hline \multicolumn{7}{|l|}{ Rams } \\
\hline \multicolumn{7}{|l|}{ Before fattening } \\
\hline Group E & $1.24^{\mathrm{a}}$ & 0.11 & $13.31^{\mathrm{a}}$ & 1.22 & $2.15^{\mathrm{bA}}$ & 0.16 \\
\hline Group C & $1.13^{a}$ & 0.09 & $12.97^{a}$ & 2.13 & $1.44^{\mathrm{aA}}$ & 0.12 \\
\hline \multicolumn{7}{|c|}{ The end of fattening } \\
\hline Group E & $1.47^{b}$ & 0.19 & $17.75^{b}$ & 3.21 & $5.28^{\mathrm{B}}$ & 0.36 \\
\hline Group C & $1.19^{a}$ & 0.15 & $13.29^{\mathrm{a}}$ & 2.12 & $2.48^{b}$ & 0.22 \\
\hline
\end{tabular}

Table 5

Body live weight and daily live weight gain of lambs to 8 weeks old

Lebendgewicht und tägliche Zunahme der Lämmer in Aufzuchtperiode

\begin{tabular}{|c|c|c|c|c|c|c|}
\hline \multirow{2}{*}{ Item } & \multicolumn{3}{|c|}{ Experimental Group (E) } & \multicolumn{3}{|c|}{ Control Group (C) } \\
\hline & $n$ & LSM & SE & $n$ & LSM & SE \\
\hline \multicolumn{7}{|l|}{ Live weight, kg } \\
\hline at birth & 41 & $4.9^{\mathrm{a}}$ & 0.13 & 41 & $5.4^{b}$ & 0.14 \\
\hline at the age 28 days & 41 & $12.1^{\mathrm{A}}$ & 0.35 & 41 & $13.6^{\mathrm{B}}$ & 0.37 \\
\hline at the age 56 days & 41 & $18.9^{A}$ & 0.50 & 41 & $21.4^{B}$ & 0.53 \\
\hline \multicolumn{7}{|c|}{ Daily live weight gain, $\mathrm{g}$} \\
\hline birth-4 week & 41 & $265.0^{\mathrm{a}}$ & 11.5 & 41 & $303.8^{\mathrm{b}}$ & 12.1 \\
\hline 4-8 week & 41 & $252.2^{\mathrm{a}}$ & 10.0 & 41 & $281.6^{\mathrm{b}}$ & 10.6 \\
\hline birth-8 week & 41 & $255.1^{\mathrm{a}}$ & 8.4 & 41 & $290.6^{b}$ & 8.9 \\
\hline
\end{tabular}

Despite these differences, the body live weight gains during fattening were similar in both groups. Rams from E groups intake less concentrate per kg body live weight gain than control group. Slaughter value of carcass and results of leg dissection presented in Table 7. Dressing percentage in rams from experimental group was similar to that found in rams from control group. Se, $\mathrm{Zn}$ and vitamin $\mathrm{E}$ treated rams contained less fat in leg $(P \leq 0.05)$, less fat thickness over ribs $(P \leq 0.01)$ and less fat thickness over loin-eye than non treated rams (Table 7). 
Table 6

Results of rams fattening

Mastleistung der Lämmer

\begin{tabular}{|c|c|c|c|c|}
\hline \multirow{2}{*}{ Item } & \multicolumn{2}{|c|}{ Experimental Group (E), $n=20$} & \multicolumn{2}{|c|}{ Control Group (C), $n=20$} \\
\hline & LSM & SE & LSM & SE \\
\hline Age at start fattening, days & 55.7 & 0.4 & 56.4 & 0.4 \\
\hline Age at slaughter & 100.9 & 2.9 & 95.2 & 2.9 \\
\hline Days of fattening & 45.3 & 2.9 & 38.8 & 2.8 \\
\hline Body weight initial, $\mathrm{kg}$ & $17.2^{\mathrm{A}}$ & 0.9 & $20.5^{\mathrm{B}}$ & 0.8 \\
\hline Body weight final, $\mathrm{kg}$ & 31.3 & 0.5 & 32.4 & 0.5 \\
\hline Body live weight gain during fattening, $\mathrm{g}$ & 316.9 & 13.2 & 317.9 & 12.9 \\
\hline Birth - start fattening, $g$ & $229.2^{\mathrm{a}}$ & 13.1 & $276.3^{\mathrm{b}}$ & 12.7 \\
\hline Intake of concentrate $/ \mathrm{kg}$ live weight gain, $\mathrm{kg}$ & 3.5 & 0.2 & 4.0 & 0.2 \\
\hline
\end{tabular}

LSM last square mean, SE standard error of mean, ${ }^{a A, b B}$ means superscripts differ significantly at a,b: $P \leq 0.05$, $\mathrm{A}, \mathrm{B}: P \leq 0.01$

Table 7

Slaughter value of carcass and results of leg dissection

Schlachtleistung und Schlachtkörperqualität der Lämmer

\begin{tabular}{|c|c|c|c|c|}
\hline \multirow{2}{*}{ Item } & \multicolumn{2}{|c|}{ Experimental Group (E), $n=20$} & \multicolumn{2}{|c|}{ Control Group (C), $n=20$} \\
\hline & LSM & SE & LSM & SE \\
\hline Dressing percentage & 48.9 & 0.4 & 49.3 & 0.4 \\
\hline \multicolumn{5}{|l|}{ Tissue composition of leg, $\mathrm{kg}$} \\
\hline meat & 1.403 & 0.029 & 1.463 & 0.028 \\
\hline fat & $0.246^{\mathrm{a}}$ & 0.007 & $0.279^{b}$ & 0.015 \\
\hline bones & 0.284 & 0.006 & 0.293 & 0.006 \\
\hline Fat thickness on loin-eye, $\mathrm{mm}$ & 1.72 & 0.13 & 2.03 & 0.13 \\
\hline Fat thickness over ribs, mm & $4.13^{\mathrm{A}}$ & 0.30 & $5.44^{\mathrm{B}}$ & 0.30 \\
\hline Loin-eye area, $\mathrm{cm}^{2}$ & 13.0 & 0.4 & 12.7 & 0.4 \\
\hline
\end{tabular}

\section{Discussion}

The initial Se, $\mathrm{Zn}$ and vitamin $\mathrm{E}$ status in blood plasma of ewes before treatment were $1.25,14.22$ and $3.41 \mu \mathrm{mol} / \mathrm{l}$. Comparison with the references values showed that the results obtained in this flock were within the physiological (regular) levels for a sheep herd. The contents of Se and $\mathrm{Zn}$ in the feeds were from 0.1 to $0.16 \mathrm{mg} / \mathrm{kg} \mathrm{DM}$ Se and 15.1 to $33.7 \mathrm{mg} / \mathrm{kg}$ DM Zn. All feeds would be considered as standard. All ewes received per day addition $0.12 \mathrm{mg} \mathrm{Se}, 60 \mathrm{mg} \mathrm{Zn}$ and $5 \mathrm{mg}$ vitamin $\mathrm{E}$ from mineral premix. The doses of $\mathrm{Se}, \mathrm{Zn}$ and vitamin $\mathrm{E}$ applied in this experiment did not result in miscarriages, stillbirth and cases of prolapsus uteri or vaginae. Daily Se intake per ram during fattening in $\mathrm{C}$ group was $0.15 \mathrm{mg}$ and $0.57 \mathrm{mg}$ in group E while the respective values for $\mathrm{Zn}$ were 29.2 $\mathrm{mg}$ and $97.2 \mathrm{mg}$. Minimal dietary Se requirements of animal species cannot be given with any accuracy. However, National Research Council (USA) suggested that Se requirement range for sheep are from 0.1 to $0.2 \mathrm{ppm}$ of feed DM (MCDOWELL 1992). Some animal experiments have suggested that dietary Se may have some beneficial effects at levels above those generally accepted as adequate (MCDOWELL 1992). Current estimates put maximum tolerable level of Se at $2 \mathrm{mg} / \mathrm{kg} \mathrm{DM}$ for the major livestock species, and no differentiation exists for tolerable levels between ruminants and nonruminants 
(MCDOWELL 1992, DAVIS et al. 2006). The maximum tolerable level of inorganic Se for sheep is much greater than $2 \mathrm{mg} / \mathrm{kg}$ DM as was suggested previously. Feeding up to 12 $\mathrm{mg}$ of selenite/ $\mathrm{kg}$ feed DM to ewes under the stresses of production (i.e., gestation and lactation) for 72 weeks did not produce any clinical or pathologic signs of Se intoxication (DAVIS et al. 2006). The NRC suggested that $Z n$ requirements for sheep vary from 20 to 33 $\mathrm{mg} / \mathrm{kg}$ feed DM. For ruminants, overt $\mathrm{Zn}$ toxicosis first appears when levels around 1000 ppm are incorporated into a natural-ingredient diet (MCDOWELL 1992).

The administration of $\mathrm{Se}, \mathrm{Zn}$ and vitamin $\mathrm{E}$ had significant negative effects on the body live weight at birth day, the body weight on week 4 and 8 and the daily body live weight gain from birth to 4 week and from birth to 8 week.

In our earlier study (GABRYSZUK 1994) conducted in the years 1987-1988 intramuscular injection of $5 \mathrm{ml} 0.1 \% \mathrm{Na}_{2} \mathrm{SeO}_{4}$ and $250 \mathrm{mg}$ of vitamin $\mathrm{E} 4$ weeks before the mating season and 4 weeks before the lambing increased fertility when the Se plasma deficit was high. However, when the Se level in blood plasma was within the normal range, the injection of vitamin $E$ and Se together decreased fertility and lamb body live weight at birth (GABRYSZUK 1994). The date obtained in earlier study indicate that single injection of Se given before mating and lambing significantly affect oestrus, fertility, lamb body weight at 28-day and daily weight gain in 0-28 days period in 3-year-old ewes (GABRYSZUK and KLEWIEC 2002). Injection of Se and vitamin E together does not significantly increased reproduction and rearing performance in 2 and 3 year old ewes in the flock considered not deficient in Se status (GABRYSZUK and KLEWIEC 2002). This may have been caused by the fact that after pregnancy and lactation the 3 year old ewes were unable to replenish the lost stores of Se and vitamin $E$ before entering the next pregnancy. Despite that the Se and vitamin E content in blood plasma were within the normal range (GABRYSZUK and KLEWIEC 2002). A positive effect of Se or Se-vitamin E on fertility was observed by several authors (SCALES 1974, MIHAILOWIČ et al. 1991, SEGERSON and GAUPATHY 1980), but not confirmed by the others (DAVIS 1966, SEGERSON et al. 1986). A divergence of opinion as regards the effect of Se on fertility was often presented in the literature. One on the reasons is due to the fact that the level of Se was rarely examined simultaneously with that of vitamin $E$ what made interpretation difficult (HIDIROGLOU 1979).

Application of $5 \mathrm{ml} 0.1 \%$ sodium selenide before mating and lambing significantly affect Se-status in blood serum and reproductive performance of ewes and body weight of lambs at 33 days of age in a Se-deficient area (BALICKA-RAMISZ et al. 2006). The mean Se blood serum content increased from 0.038 to $0.175 \mu \mathrm{g} / \mathrm{ml}$ after Se application. Body live weight lambs on birth and body live weight at 33 day significantly increased from 3.73 and $11.19 \mathrm{~kg}$ to 3.96 and $11.50 \mathrm{~kg}$ in treatment group, respectively (BALICKA-RAMISZ et al. 2006). Another study has shown that Se-vitamin E injection (with $0.31 \mathrm{mg} \mathrm{Se}+4.2 \mathrm{UI}$ vitamin $\mathrm{E}$ per kg body weight) increased the blood Se concentration in pregnant goats in selenium-deficient dairy goats (RAMIREZ-BRIBIESCA et al. 2005). It also concluded that the treatment with the single dosage as sodium selenite-vitamin E mixture injected in to kids is effective to enhance the survival of kids until weaning (RAMIREZ-BRIBIESCA et al. 2005). An increased dose of Se in lambs diet up to $0.25 \mathrm{ppm}$, as sodium selenite added to the basal natural diet containing marginally low Se $(0.082 \mathrm{ppm})$, appears to be at or near 
the Se requirement, as evidence by the level of Se in tissue, blood, serum and the maximal tissue glutathione peroxidase activities. In sheep with higher dietary Se levels $(0.41$ and $0.58 \mathrm{ppm})$, the increase in the concentration of Se and in enzyme activity was not so evident (ZACHARA et al. 1993).

The results presented here show that before offering Se and vitamin $E$ it is necessary to determine their actual level in the flock in question. OVERNES (1993) reported that adequate measures should therefore be taken to ensure that animals receive an optimal supplementation of both Se and vitamin E. The reasons for the discrepancies in various reports may be related to the level of Se and the interaction of Se or Se-E with other nutrition factors. Se and Se+E supplementation, when plasma Se concentration was within the standard range, appeared to contribute to a healthier udder status, but neither lamb weaning weights nor ewe productivity were enhanced by the treatment applied (APPEDDU et al. 1994).

In study of GABRYSZUK et al. (2005) simultaneous injections of $\mathrm{Se}, \mathrm{Zn}$ and vitamin $\mathrm{E}$ at 4 weeks before lambing does not increased level of these nutrients in colostrum. The second injection on 1 day after lambing slightly increased Se and Zn levels one week after lambing. The level of vitamin $E$ also increased, but not significantly. The next injections at 3 and 6 weeks after lambing significantly increased Se levels at 4, 6 and 7 weeks after parturition, vitamin E levels at 4 and 7 weeks, and $Z n$ levels significantly increased 7 weeks after lambing (GABRYSZUK et al. 2005). MENESES et al. (1994) showed that ewes injected with vitamin $\mathrm{E}$ and $\mathrm{Se}$ at lambing had a significantly higher vitamin $\mathrm{E}$ and $\mathrm{Se}$ in the milk than control group up to 14 day of the lactation. Ewes receiving two prepartum injection of the highest Se dose had higher milk Se concentration than controls at both parturition and 1 month later (CUESTA et al. 1995). Se, Zn and vitamin E administered intramuscular to pregnant and lactating ewes induced a decrease in cholesterol content of milk and blood, and led to increased the conjugated linoleic acid (CLA) isomers level in milk (GABRYSZUK et al. 2007b).

The initial Se, $\mathrm{Zn}$ and vit. E status in blood plasma of fattening rams were within the physiological (regular) levels for a sheep herd (Table 4). The concentrations of Se, $\mathrm{Zn}$ and vit. $E$ in the blood plasma of rams from group $E$ after fattening were significantly higher than control rams, but within the reference values (Table 4). In the same age at start fattening rams weaned from ewes treated $\mathrm{Se}, \mathrm{Zn}$ and vitamin $\mathrm{E}$ were lower body weight initial fattening and lower body live weight gain from birth to start fattening than rams from control group (Table 6). Despite above differences the daily live weight gains during fattening were similar in both groups. Rams from $\mathrm{E}$ groups intake less concentrate per $\mathrm{kg}$ body live weight gain than control group, but not statistically confirmation. The results of fattening and slaughter value of all lambs examined in the current work was satisfactory and comparable to the results reached in the other experiment conducted on growing lambs (BARANOWSKI et al. 2007). Dressing percentage in rams from experimental group was similar to that found in rams from control group. In comparison to the $\mathrm{C}$ diet, enrichment of diet $\mathrm{E}$ with $\mathrm{Se}, \mathrm{Zn}$ and vitamin $\mathrm{E}(0.42$, 68 and $60 \mathrm{mg} / \mathrm{lamb} / \mathrm{day}$, respectively) significantly decreased the fat in leg, fat thickness over ribs and fat thickness over loin-eye (Table 7). In study of GABRYSZUK et al. (2007a) demonstrated that Se, Zn and vitamin $\mathrm{E}$ administered orally to growing ram-lambs induced a decrease in total 
cholesterol content of blood and meat and increase the hight density lipoproteins fractions level in blood. Additionally enrichment the diet of $\mathrm{Se}, \mathrm{Zn}$ and vitamin $\mathrm{E}$, led to increased the CLA isomers level in meat and liver.

BORYS et al. (2004) reported, that the experimental diets (10\% of rapeseed and linseed oil) enriched with vit. E decreased fat layer over the loin eye (by $41,7 \%)$, over the ribs (31.7\%), and decreased by the average of $11.5 \%$ of intramuscular fat of lambs meat, but no statistically confirmation. The use of $10 \%$ oilseeds in complete diets for lambs did not significantly affect fattening results and slaughter value. Generally more favourable parameters were obtained when feeding rapeseed and linseed at a 1:1 ratio than at a 2:1 ratio and when the diets were supplemented with vitamin $\mathrm{E}$ (BORYS and JARZYNOWSKA, 2005).

The male Polish Merino lambs fed the experimental diets enriched in $5 \%$ linseed oil (LO) or $2 \mathrm{ppm}$ Se (SE) numerically increased the body weight of lambs. While the combined addition of 5\% LO and 2 ppm Se (LOSE) significantly elevated body weight after 35 days of feeding (CZAUDERNA et al. 2004). Feeding the diet enriched in LO or in LO and Se (LOSE) resulted in numerically increased mass of the liver, lungs, spleen, kidneys, M. longissimus dorsi and M. biceps femoris (CZAUDERNA et al. 2004).

This study demonstrated that levels of $\mathrm{Se}, \mathrm{Zn}$ and vitamin $\mathrm{E}$ in blood plasma were within the reference values before and after $\mathrm{Se}, \mathrm{Zn}$ and vitamin $\mathrm{E}$ administered to ewes and fattening rams. Se, $\mathrm{Zn}$ and vitamin $\mathrm{E}$ administered intramuscularly to pregnant and lactating ewes induced a decrease body live weight at birth, body live weight at 4 and 8 week, daily live weight gain from birth to 4 week and from birth to 8 week. Administered of $\mathrm{Se}, \mathrm{Zn}$ and vitamin E orally to growing ram-lambs induced a decrease content of fat in leg, fat thickness on loin-eye and fat thickness over ribs. The daily body live weight gain during fattening was similar in experimental group and in control group. The results presented here show that before offering $\mathrm{Se}, \mathrm{Zn}$ and vitamin $\mathrm{E}$ it is necessary to determine their actual level in the flock in question.

\section{Acknowledgements}

The State Committee for Scientific Research, grant No. 6 P06Z 01921, supported this study.

\section{References}

Antunovi Z, Speranda M, Steiner Z (2004) The influence of age and the reproductive status to the blood indicators of the ewes. Arch Tierz 47, 265-73

Appeddu LA, Ely DG, Aaron DK, Deweese WP (1994) Response of lactating ewes to injections of selenium and vitamin E. J Anim Sci 72, 11-9

Balicka-Ramisz A, Pilarzyk B, Ramisz A, Wieczorek M (2006) Effects of selenium administration on blood serum Se content and on selected reproductive characteristics of sheep. Arch Tierz 49, 176-80

Baranowski A, Gabryszuk M, Jóźwik A, Bernatowicz E, Chyliński W (2007) Fattening performance slaughter indicators and meat chemical composition in lambs fed the diet supplemented with linseed and mineral bioplex. Anim Sci Papers and Reports 25, 35-44

Borys B, Borys A, Gąsior R (2004) Effect of feeding rapeseed and linseed diets and their supplementation with vitamin $\mathrm{E}$ on health quality of lamb meat. Arch Tierz $47 \mathrm{SI}, 189-97$

Borys B, Jarzynowska A (2005) Effects of vitamin E supplemented to rapeseed and linseed diets on the slaughter value of lambs. J Anim Feed Sci 14 Suppl 1, 227-30

Capper JL, Wilkinson RG, Kasapidou E, Pattinsom SE, Mackenzie AM, Sinclair L (2005) The effect of dietary vitamin $\mathrm{E}$ and fatty acid supplementation of pregnant and lactating ewes on placental and mammary transfer of vitamin E to lamb. Brit J Nutr 93, 549-57 
Cąkała S (1981): Diseases of sheep. PWRiL Warsaw [in Polish]

Cuesta PA, McDowell LR, Kunkle WE, Wilkinson NS, Martin FG (1995) Effects of high-dose prepartum injections of Se and vitamin E on milk and serum concentrations in ewes. Small Rumin Res 18, 99-103

Czauderna M, Kowalczyk J, Niedźwiedzka KM, Wąsowska I, Pająk JJ (2004) The effect of selenium and linseed oil on growth of sheep and content of selected fatty acids in M longisimus doorsi. J Anim Feed Sci 13, Suppl 2 105-8

Davis HL (1966) The effect of selenium and vitamin E on reproduction in Merino sheep in southwester Australia. J Aust Inst Agric Sci 32, 216-22

Davis PA, Mcdowell LR, Wilkinson NS, Burgelt CD, Van Alstyne R, Weldon RN, Marshall TT (2006) Tolerance of organic selenium by range-type ewes during gestation and lactation. J of Anim Sci 84, 660-8

Doncon GH, Steele P (1988) Plasma and liver concentrations of $\alpha$-tocopherol in weaned sheep after vitamin E supplementation. Aust Vet J 65, 210-3

Gabryszuk M (1994) The effect of selected minerals and vitamin E on the reproduction of the Polish Merino Sheep. II. Reproduction and rearing lambs. Anim Sci Papers and Reports 12, 53-61

Gabryszuk M, Czauderna M, Baranowski A, Strzałkowska N, Jóźwik A, Krzyżewski J (2007a) The effect of diet supplementation with Se $\mathrm{Zn}$ and vitamin $\mathrm{E}$ on cholesterol CLA and fatty acid contents of meat and liver of lambs. Anim Sci Papers and Reports 25, 25-33

Gabryszuk M, Czauderna M, Gralak MA, Antoszkiewicz Z (2005) Effects of pre- and postpartum injections of Se $Z n$ and vitamin $E$ on their concentration in ewes milk. J Anim Feed Sci 14 Suppl 1, 255-8

Gabryszuk M, Klewiec J (2002) Effect of injecting 2- and 3-year-old ewes with selenium and seleniumvitamin $\mathrm{E}$ on reproduction and rearing of lambs. Small Rumin Res 43, 127-32

Gabryszuk M, Strzałkowska N, Krzyżewski J (2007b) Effects of pre- and post-partum injections of Se Zn and vitamin $\mathrm{E}$ on the concentration of cholesterol CLA isomers and fatty acids in ovine milk. Anim Sci Papers and Reports 25, 87-95

Harvey WR (1990) Mixed model least-squares and maximum likelihood computer program Ohio State University USA

Hidiroglou M (1979) Trace element deficiencies and fertility in ruminants: a review. J Dairy Sci 62, 1195-206

Hidiroglou M, McAllister AJ, Williams CJ (1987) Prepartum supplementation of selenium and vitamin E to dairy cows: Assessment of selenium status and reproductive performance. J Dairy Sci 70, 1281-8

Judson GJ, Brown TH, Kempe BR, Turnbull RK (1988) Trace element and vitamin B12 status of sheep given an oral dose of one two or four soluble glass pellets containing copper selenium and cobalt. Aust J Exp Agr 28, 299-305

Koller LD, Whitbeck GA, South PJ (1984) Trans-placental transfer and colostrum concentrations of selenium in beef cattle. Am J Vet Res 45, 2507-10

Kolodziej A, Jacyno E (2005) Effect of selenium and vitamin $E$ supplementation on reproductive performance of young boars. Arch Tierz 48, 68-75

Krsk P, Lahucky R, Küchenmeister U, Nürnberg K, Palanska O, Bahelka I, Kuhn G, Ender K (2001) Effect of dietary organic selenium and vitamin $\mathrm{E}$ supplementation on post mortem oxidative deterioration in muscles of pigs. Arch Tierz 44, 193-201

Langlands JP, Donald GE, Bowles JE, Smith AJ (1991) Subclinical selenium insufficiency. 3. The selenium status and productivity of lambs born to ewes supplemented with selenium. Aust J Exp Agric 31, 37-43

MAFF (Ministry of Agriculture Fisheries and Food) (1975) Energy Allowances and Feeding Systems for Ruminants. London, Tech Bull No 33

McDowell LR (1979) Minerals in Animal and Human Nutrition. Academic Press Inc San Diego USA

McMurray CH, Blanchflower WJ (1979) Application of a high-performance liquid chromatographic fluorescence method for the rapid determination of $\alpha$-tokoferol in the plasma of cattle and pigs and its comparison with direct fluorescence and high-performance liquid chromatography-ultraviolet detection methods. J Chromatogr 178, 525-31

Meneses A, Batra TR, Hidiroglou M (1994) Vitamin E and selenium in milk of ewes Can J Anim Sci 74, 567-9

Mihajlovič M, Lindeberg P, Rajkovič M (1991) Selenium content in foodstuffs and selenium status of sheep in some areas of Serbia. In: Momčilowič B (Ed), Trace elements in man and animal IMI Zagreb 7, 11-27

Njeru CA, McDowell LR, Wilkinson NS, Linda SB, Williams SN (1994) Pre- and post-partum supplemental $\mathrm{DL}-\alpha$-tocopheryl acetate effects on placental and mammary vitamin $\mathrm{E}$ transfer in sheep. J Anim Sci $72,1636-40$

Øvernes G (1993) Selenium supplementation in ruminants Nor J Agric Sci 11, 199-203 
Ramirez-Bribiesca JE, Tortora JL, Huerta M, Hernandez LM, Lopez R, Crosby M (2005) Effect of seleniumvitamin $\mathrm{E}$ injection in selenium-deficient dairy goats and kids on the Mexican plateau. Arq Bras Med Vet Zootec 57, 77-84

Scales GH (1974) Reproductive performance of Merino ewes dosed with selenium prior to mating. Proc N Z Soc Anim Prod 34, 103-3

Segerson EC, Ganapathy SN (1980) Fertilisation of ova in selenium / vitamin E treated ewes maintained on two planes of nutrition. J Anim Sci 51, 386-94

Segerson EC, Gunsett FC, Getz WR (1986) Selenium-vitamin E supplementation and production efficiency in ewes marginally deficient in selenium. Livest Prod Sci 14, 149-59

Underwood EJ, Suttle NF (1999) The mineral nutrition of livestock. 3rd ed, CAB International Wallingford Oxon UK

Zachara BA, Trafikowska U, Labecka H, Mikołajczak J (1993) Effect of dietary Se intake on blood Se levels and glutathione peroxidase activities in lambs. Small Rumin Res 9, 331-40

Received 14 January 2008, accepted 12 February 2009.

Corresponding author:

MIROSŁAW GABRYSZUK, Doc PhD DSc

email: m.gabryszuk@ighz.pl

Institute of Genetics and Animal Breeding, Polish Academy of Sciences, Jastrzębiec, 05-552 Wólka Kosowska, Poland 